\title{
Designing Organizational Culture Through the $Z$ Theory Modification in the Environment of CV. Indobenua Global Mandiri, Sidoarjo
}

\author{
Tiffany Esperances Deandra ${ }^{1}$, I Gede Arimbawa ${ }^{2}$, Elok Damayanti $^{3}$ \\ Faculty of Economics and Business Management Study Program Narotama University Surabaya ${ }^{1,2,3}$ \\ tiffanyesperances@gmail.com ${ }^{1}$, gede.arimbawa@narotama.ac.id ${ }^{2}$, elok.damayanti@narotama.ac.id ${ }^{3}$
}

\begin{abstract}
Purpose: This study aims to designing organizational culture through the $Z$ Theory modification in the environment of $C V$. Indobenua Global Mandiri, Sidoarjo.

Design/methodology/approach: This study used a qualitative research approach and post positivism philosophy method,

Findings: The results of organizational culture design in CV. Indobenua Global Mandiri Sidoarjo formed through modification of the value system derived from $Z$ theory, such as: implicit control mechanism and the prevailing culture in the CV. Indobenua Global Mandiri,

Research limitations/implications: $C V$. Indobenua Global Mandiri, Sidoarjo.

Practical implications: harmonizing relationships among employees, and responsibilities according to job description, and control mechanisms by superiors directly.

Originality/value:

Paper type: This paper can be categorized as case study paper.
\end{abstract}

Keywords: Organizational culture, Z Theory, Analytical hierarchical process .

Received : June $10^{\text {th }} 2019$

Revised : July $17^{\text {th }} 2019$

Published : September $30^{\text {th }} 2019$

\section{INTRODUCTION}

Organizational culture is closely related to the values possessed by individuals. This organizational culture greatly influences the culture of the workplace and the nature of the work itself, but the organizational culture of the company can have a goal that is to be able to create the identity of employees and can help motivate employees themselves and in achieving the goals set. Besides that, organizational culture has positive and negative influences, so employees can give responsibility, and can make decisions together, this is with a poor working environment that can demand labor and not support a work system that is not good for employees.

From the results of identification with several employees who are out and absent on average generally express complaints about the work environment, career obscurity, and the absence of values that can improve work culture. According to Robbins in Muhammad Ali (2012) states that organizational culture involves a shared system of meanings / values, which functions as an effective independent variable to influence the behavior of organizational members to improve their respective performance based on the organization's defined vision and mission (Dr. Muhammad Ali, 2012). William G. Ouchi (1981) argues that the motivation of individual hard work is related to where the individual works, in other words related to the leadership of how to lead the organization. Some research results that support and criticize the Z Theory, such as: Hermawan, 2009, the results of the study say that the seven principles of $Z$ theory are produced from Japanese culture so as to create high productivity. Modifying the $\mathrm{Z}$ theory is in accordance with Indonesian culture so as to create high productivity . But to modify it needs adjustments according to culture, the times and globalization. Lee 
and Mushin, 1992 in a study entitled Samsung Uses Z Theory to become a living organization, the results of his research found that: 1) The duration of work is not short term or lifetime.2) Organizational culture respects the collective approach, not individual actions, about how to take decision.3) Responsibility is carried out by individuals.4) Frequency of low employee evaluation.5) Control depends on formal-informal and explicit-formal steps.6) Career paths are specifically specified and there are holistic concerns for employees above all seem to support the application of $\mathrm{Z}$ theory, but other research results show different things as stated by: Sullivan, 1986. The results of his research criticize Ouchi's statement that Japan is an industrial society where Z theory has developed to receive limited support from research findings, besides, Ouchi's foundation of theory in humanistic management does not seem to be reasoned George, 1986 Japan and America Management: Z Theory and Beyond. The results of the analysis say that 1$)$. $Z$ management theory may not be the norm accepted in American companies as far as Japan exists.2) The main conceptual or theoretical lessons we can learn from Japanese management is internally consistent, which is in accordance with the norms and expectations of the community and who get support from the main institutional actors in the world of work.

How to practice the application of $Z$ Theory in Indonesia, the implementation of the $Z$ Theory in Pembangunan Jaya Group, states that 1 ) his belief in $Z$ Theory can be applied in Indonesia because it is in accordance with the noble values contained in the philosophy of our country, Pancasila, 2) in each company still needs to prepare its requirements as the preconditions needed. Based on the phenomena and gaps (gaps) of the above research, the author proposes the topic research en titled Organizational Culture through Modification of Z Theory in the Environment Cv.Indobenua Global Mandiri in Sidoarjo.

\section{LITERATUR REVIEW Organizational culture theory}

Organizational culture is concerned with how employees perceive the characteristics of an organizational culture, not whether employees like culture or not. Culture distinguishes people from one another in ways of interacting and acting on a job. Culture ties community members into a unity of views that creates uniformity in behavior or acting. Along with the passage of time culture must be formed within the organization and benefits can also be felt in contributing to the overall effectiveness of the organization. According to Tosi, Rizzo, Carrol (Source of Organizational Culture, 2001) as quoted by Munandar (2001: 264), organizational culture is influenced by several factors, namely: 1) General influences from the broad outside Include factors that are not can be controlled or only slightly controlled by the organization 2) The influence of the values that exist in the community Beliefs and values that are dominant from the wider community such as politeness and cleanliness 3 ) Factors that are specific to the organization Organizations always interact with their environment. addressing both external and internal problems of the organization will get successful solutions. Success in overcoming these problems is the basis for the growth of organizational culture.

The purpose of implementing organizational culture is so that all individuals in a company or organization adhere to and are guided by a system of values of beliefs and norms that apply in the company or organization (AAAnwar Prabu Mangkunegara, 2005).

\section{Z Theory}

Z Theory was created by William G Bill Ouchi, a professor from the United States and a book writer in the field of management. Z Theory has been implemented / implemented in various companies in the United States and Japan. Z Theory places more emphasis on the role and position of employees or employees in the company that can make workers more comfortable, more comfortable, more happy and feel an important part of the company. Thus the employee will work more effectively and efficiently in doing the work he does. The 
following are the terms and characteristics of a company that applies the $\mathrm{Z}$ theory:

1. Responsibility is given individually or individually.

2. Employees are free to work using the skills they have.

3. Employees are employed for life and if the company experiences a crisis, the employees will not be fired or term.

4. Decision making is done by consensus or openly. Although it will take longer but remember the success of implementing the results of the decisions obtained will be higher because it has the support of the majority of workers.

5. Promotion is carried out slowly from the bottom, and the process of evaluating achievements and promotions is done carefully so as not to cause problems with employees.

\section{$\mathrm{Z}$ theory principles:}

1. Life time employment is more than just a single policy, is the basis on which many aspects of life and work are integrated. The benefits obtained by the company from such policies include stable labor, thus increasing the loyalty of company workers, and ultimately increasing efficiency and productivity.

2. Slow promotion and evaluation (relatively slow promotion and evaluation process) are capable people who easily and quickly accept responsibility, but indisputable promotional steps will be obtained if they have proven their ability to call it.

3. Specialized career paths are those that move from one job to another in the company, especially in their initial year. This movement allows employees to learn about various aspects of the company. This also minimizes crises if there are, for example: employees who are sick/not entering or on leave.

4. Conceptual decision making (decision according to consensus) is a Manager involving workers to be able to provide useful input in company decision decisions because workers at the workstation level understand every step in the company's production process.

5. Collective responsibility (collective responsibility) is collective decision making followed by collective responsibility. In companies that apply the $\mathrm{Z}$ Theory, teams (not individuals), are rewarded because all achievements are team efforts. Collective responsibility also means that appreciation, praise, and achievement are shared among all members.

6. The explicit control mechanism is that $\mathrm{Z}$ Theory shows an implicit control mechanism, which comes from sharing goals and values of common values. Theories are communicated through a common culture together with key managers and to all employees.

7. Holistic concern (thorough attention to employees) is $\mathrm{Z}$ Theory develops a thorough attention to employees; including family life, social life, health and retirement

Holistic concern (thorough attention to employees) is $\mathrm{Z}$ Theory develops a thorough attention to employees; including family life, social life, health and retirement

\section{METHODOLGY}

This study used a qualitative approach that is a research method based on the philosophy of postpositivism, used to examine the condition of natural objects. Then a qualitative approach to human resource problems in CV. Indobenua Global Mandiri Sidoaro.The results are to design organizational culture through modification of $\mathrm{Z}$ Theory in the environment of CV. Indobenua Global Mandiri in Sidoarjo.

This study used data analysis techniques in the form of an Analyst Hierarchy Process (AHP), which is one analysis tool that allows to make decisions for complex problems. according Saaty (1993), hierarchy is defined as a representation of a complex problem in a multi-level structure where the first level is a goal, followed by a factor level, criteria, sub criteria, and so on down to the last level of the alternative. In general, using AHP, the priorities generated will be consistent with the theory, logical, 
transparent and participatory. AHP will be very suitable to be used for prioritizing public policies that demand transparency and participation. Broadly speaking, the AHP procedure includes the following stages:

1. Decomposition

The problem decomposition is the step in which a goal (Goal) that has been determined is then systematically described into the structure that composes the system sequence so that the objectives can be achieved nationally.

2. Assessment or weighting to compare elements

If the decomposition process has been completed and the hierarchy has been well structured. Furthermore, a comparison of pairing (weighting) is carried out in each hierarchy based on the level of relative importance.

3. Preparation of matrices and Consistency Tests

If the weighting process or filling in the questionnaire has been completed, the next step is the preparation of a paired matrix to normalize the level of importance in each of the hierarchies. At this stage the analysis can be done manually or by using a program a computer like Expect Choice.

4. Determination of priorities in each hierarchy

For each criteria and alternative, it is necessary to do pair comparisons. The values of relative comparison are then processed to rank alternatives from all alternatives. Both qualitative and quantitative criteria can be compared according to the predetermined assessment for produce weights and priorities.

5. Synthesis of priorities

Synthesis of priorities is obtained from the results of multiplying local priorities with the priority of the relevant criteria at the top level and adding them to each element in the level affected by the criteria.

\section{RESEARCH FLOW FRAMEWORK}

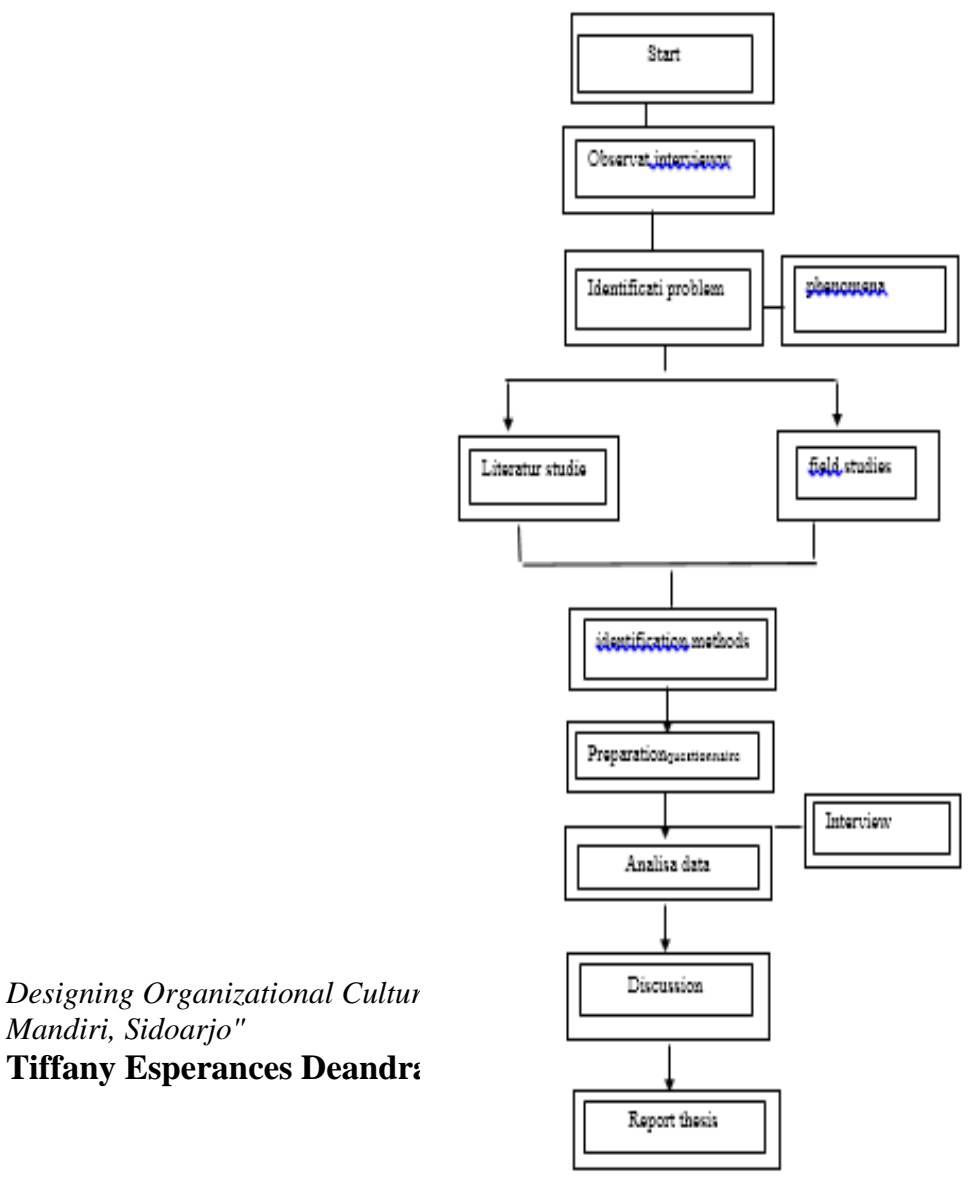




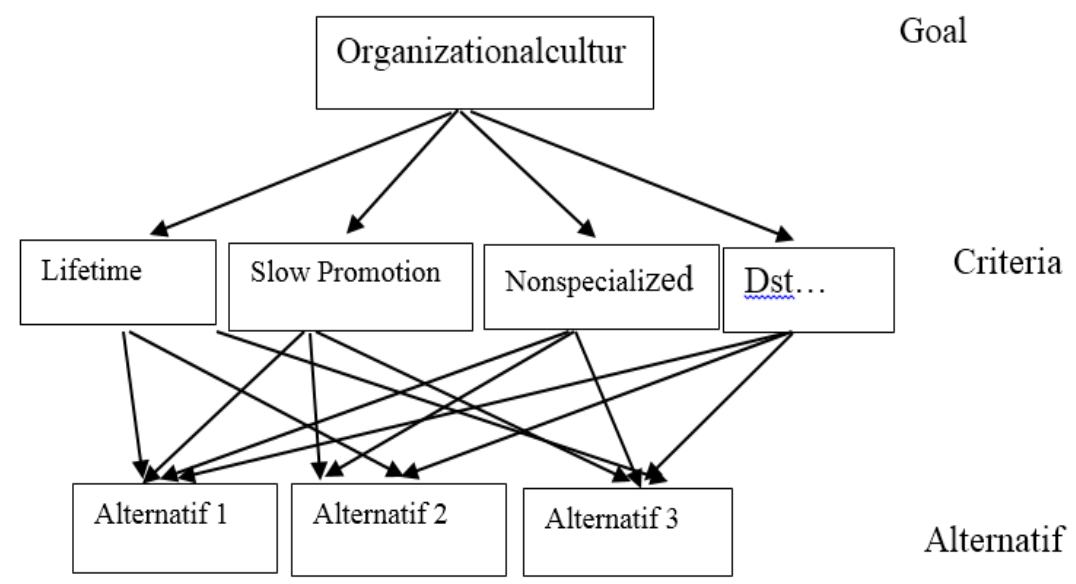

Figure 1: Organizational Culture Hierarchy Structure

\section{Scale measurement}

\begin{tabular}{|c|c|c|}
\hline $\begin{array}{l}\text { Intennsity } \\
\text { of interest }\end{array}$ & $\begin{array}{l}\text { Variabel } \\
\text { Definition }\end{array}$ & Explanation \\
\hline 1 & Equally important & Both elements have the same effect \\
\hline 3 & $\begin{array}{l}\text { Slightly more } \\
\text { important }\end{array}$ & The judgment favored one element \\
\hline 5 & More important & The assessment is very siding with one element \\
\hline 7 & Very important & $\begin{array}{l}\text { Evidence that one element is very influential and its } \\
\text { dominance is clearly visible }\end{array}$ \\
\hline 9 & $\begin{array}{c}\text { Dominance } \\
\text { bsolutemore } \\
\text { isimportant }\end{array}$ & $\begin{array}{l}\text { Evidence that an element more important than the partner is } \\
\text { very clar }\end{array}$ \\
\hline $2,4,6,8$ & $\begin{array}{c}\text { Value assessment } \\
\text { central above the } \\
\text { of } \\
\text { value }\end{array}$ & The value given if there are doubts between the two choices \\
\hline Resiprokal & \multicolumn{2}{|c|}{$\begin{array}{l}\text { If the comparison between elements } i \text { and } j \text { produces one the value above ,the } \\
\text { comparison between elements } i \text { and } j \text { will produce the opposite value }\end{array}$} \\
\hline
\end{tabular}

Source: Saaty, 1990

1. Pairwise comparison

matrix Table 1 Comparative Matrix of Alternative Pairing

\begin{tabular}{|l|l|l|l|l|l|l|l|l|l|l|l|l|l|l|}
\hline & Le & Sp & Ns & Cd & Cr & Ic & Wc & St & Ep & Jk & Mk & Tj & Pk & Hh \\
\hline
\end{tabular}

Designing Organizational Culture Through The Z Theory Modification In The Environment Of Cv. Indobenua Global Mandiri, Sidoarjo"

Tiffany Esperances Deandra ${ }^{1}$, I Gede Arimbawa ${ }^{2}$, Elok Damayanti $^{3}$ 


\begin{tabular}{|c|c|c|c|c|c|c|c|c|c|c|c|c|c|c|}
\hline Le & 1.00 & 0.50 & 1.00 & 0.50 & 0.50 & 1.00 & 0.50 & 0.50 & 0.50 & 0.50 & 0.50 & $\begin{array}{r}0.3 \\
3\end{array}$ & 0.33 & $\begin{array}{r}0.3 \\
3\end{array}$ \\
\hline $\mathrm{Sp}$ & 2.00 & 1.00 & 1.00 & 0.50 & 1.00 & 1.00 & 0.50 & 0.50 & 1.00 & 0.50 & 1.00 & $\begin{array}{r}1.0 \\
0\end{array}$ & 0.50 & $\begin{array}{r}0.5 \\
0\end{array}$ \\
\hline Ns & 1.00 & 1.00 & 1.00 & 0.50 & 1.00 & 1.0 & 1.00 & 0.50 & 0.50 & 0.50 & 0.50 & $\begin{array}{r}0.5 \\
0\end{array}$ & 0.33 & $\begin{array}{r}0.2 \\
0\end{array}$ \\
\hline $\mathrm{Cd}$ & 2.00 & 1.00 & 2.00 & 1.00 & 2.00 & 2.00 & 2.00 & 1.00 & 1.00 & 1.00 & 1.00 & $\begin{array}{r}0.5 \\
0\end{array}$ & 0.50 & $\begin{array}{r}0.5 \\
0\end{array}$ \\
\hline $\mathrm{Cr}$ & 2.00 & 1.00 & 1.0 & 1. & 1.00 & 1.00 & 1.00 & 0 & 0.50 & 0. & 0.50 & $\begin{array}{r}0.5 \\
0\end{array}$ & 0.50 & $\begin{array}{r}0.5 \\
0\end{array}$ \\
\hline Ic & 3.00 & 2.00 & 3.00 & 2.00 & 2.00 & 1.00 & 2.00 & 2.00 & 2.00 & 0.33 & 0.33 & $\begin{array}{r}0.3 \\
3\end{array}$ & 1.00 & $\begin{array}{r}1.0 \\
0\end{array}$ \\
\hline $\begin{array}{l}\text { W } \\
\mathrm{c}\end{array}$ & 2.00 & 2.0 & 1.00 & 1.00 & 1.00 & 1.00 & .00 & 1.00 & 0.50 & 1.00 & 0.50 & $\begin{array}{r}0.5 \\
0\end{array}$ & 0.50 & $\begin{array}{r}0.5 \\
0\end{array}$ \\
\hline $\mathrm{St}$ & 2.00 & 2.00 & 2.00 & 2.00 & 2.00 & 2.00 & 1.00 & 1.00 & 1.00 & 1.00 & 0.50 & $\begin{array}{r}0.5 \\
0\end{array}$ & 1.00 & $\begin{array}{r}0.5 \\
0\end{array}$ \\
\hline Ep & 2.0 & 2.00 & 2.0 & 1.0 & 1.00 & 1. & 1.00 & 50 & 00 & 0.50 & 0.50 & $\begin{array}{r}1.0 \\
0\end{array}$ & 0.5 & $\begin{array}{r}0.5 \\
0\end{array}$ \\
\hline $\mathrm{Jk}$ & 2.00 & 1.00 & 2.00 & 2.00 & 2.00 & 2.00 & 1.00 & 1.00 & 00 & 1.00 & 0.20 & $\begin{array}{r}0.5 \\
0\end{array}$ & 1.00 & $\begin{array}{r}0.5 \\
0\end{array}$ \\
\hline $\begin{array}{c}\mathrm{M} \\
\mathrm{k}\end{array}$ & 2.00 & 1.00 & 2.00 & 2.00 & 2.00 & 2.00 & 2.00 & 2.00 & 1.00 & 5.0 & 1.0 & $\begin{array}{r}0.5 \\
0\end{array}$ & 2.00 & $\begin{array}{r}0.5 \\
0\end{array}$ \\
\hline $\mathrm{Tj}$ & 3.00 & 1.0 & 2.0 & 1. & 2.00 & 2.00 & 2.00 & 2.00 & 2.00 & 2.00 & .00 & $\begin{array}{r}1.0 \\
0\end{array}$ & 2.00 & $\begin{array}{r}0.5 \\
0\end{array}$ \\
\hline pk & 1.00 & 1.00 & 1.00 & 1.00 & 1.00 & 1.00 & 1.00 & 0.50 & 0.50 & 0.50 & 0.50 & $\begin{array}{r}0.5 \\
0\end{array}$ & 1.00 & $\begin{array}{r}0.5 \\
0\end{array}$ \\
\hline $\mathrm{Hh}$ & 3.00 & 2 & 5.0 & 2.00 & 2.00 & 2.00 & 2.00 & 2.00 & 2.00 & 2.00 & 2.00 & $\begin{array}{r}2.0 \\
0\end{array}$ & 1.00 & $\begin{array}{r}1.0 \\
0\end{array}$ \\
\hline & $\begin{array}{c}28.0 \\
0\end{array}$ & $\begin{array}{c}18.5 \\
0\end{array}$ & $\begin{array}{c}26.0 \\
0\end{array}$ & $\begin{array}{c}17.5 \\
0\end{array}$ & $\begin{array}{c}20.5 \\
0\end{array}$ & $\begin{array}{c}20.0 \\
0\end{array}$ & $\begin{array}{c}18.0 \\
0\end{array}$ & $\begin{array}{c}15.0 \\
0\end{array}$ & $\begin{array}{c}14.5 \\
0\end{array}$ & $\begin{array}{c}16.3 \\
3\end{array}$ & $\begin{array}{c}11.0 \\
3\end{array}$ & $\begin{array}{c}9.6 \\
7\end{array}$ & $\begin{array}{c}12.1 \\
7\end{array}$ & $\begin{array}{c}7.5 \\
3 \\
\end{array}$ \\
\hline
\end{tabular}

Source: AHP Manual Calculation (using Ms.Excel)

2. Normalization Mathematics

Table 2 Alternative Normalization Matrix

\begin{tabular}{|c|c|c|c|c|c|c|c|c|c|c|c|c|c|c|c|c|}
\hline & Le & Sp & Ns & Cd & $\mathrm{Cr}$ & Ic & Wc & St & $\mathbf{E p}$ & $\mathbf{J k}$ & Mk & $\mathbf{T} \mathbf{j}$ & Pk & Hh & $\begin{array}{c}\text { jumla } \\
\mathbf{h}\end{array}$ & EP \\
\hline \multirow{2}{*}{ Le } & 0.0 & 0.0 & 0.0 & 0.0 & 0.0 & 0.0 & 0.0 & 0.0 & 0.0 & 0.0 & 0.0 & 0.0 & 0.0 & 0.0 & \multirow{2}{*}{0.48} & 0.0 \\
\hline & 4 & 3 & 4 & 3 & 2 & 5 & 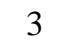 & 3 & 3 & 3 & 5 & 3 & 3 & 4 & & 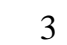 \\
\hline \multirow{2}{*}{ Sp } & 0.0 & 0.0 & 0.0 & 0.0 & 0.0 & 0.0 & 0.0 & 0.0 & 0.0 & 0.0 & 0.0 & 0.1 & 0.0 & 0.0 & \multirow{3}{*}{0.75} & 0.0 \\
\hline & 7 & 5 & 4 & 3 & 5 & 5 & 0 & 3 & 7 & 3 & 9 & 0 & 4 & 7 & & $\tau$ \\
\hline \multirow{2}{*}{ Ns } & 0.0 & 0.0 & 0.0 & 0.0 & 0.0 & 0.0 & 0.0 & 0.0 & 0.0 & 0.0 & 0.0 & 0.0 & 0.0 & 0.0 & & 0.0 \\
\hline & 4 & 5 & 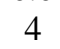 & 3 & 5 & 5 & . & 3 & 3 & 3 & 5 & 5 & 3 & 3 & \multirow[t]{2}{*}{0.56} & 4 \\
\hline \multirow{2}{*}{ Cd } & 0.0 & 0.0 & 0.0 & 0.0 & 0.1 & 0.1 & 0.1 & 0.0 & 0.0 & 0.0 & 0.0 & 0.0 & 0.0 & 0.0 & & 0.0 \\
\hline & 7 & 5 & 8 & 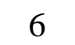 & 0 & 0 & 1 & 7 & 7 & 6 & 9 & 5 & 4 & 7 & \multirow[t]{2}{*}{1.01} & 7 \\
\hline \multirow{2}{*}{$\mathrm{Cr}$} & 0.0 & 0.0 & 0.0 & 0.0 & 0.0 & 0.0 & 0.0 & 0.0 & 0.0 & 0.0 & 0.0 & 0.0 & 0.0 & 0.0 & & 0.0 \\
\hline & 7 & 5 & 4 & 6 & 5 & 5 & 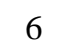 & 3 & 3 & 3 & 5 & 5 & 4 & 7 & \multirow[t]{2}{*}{0.68} & 5 \\
\hline \multirow[b]{2}{*}{ Ic } & 0.1 & 0.1 & 0.1 & 0.1 & 0.1 & 0.0 & 0.0 & 0.1 & 0.1 & 0.0 & 0.0 & 0.0 & 0.0 & 0.1 & & 0.0 \\
\hline & 1 & 1 & 2 & 1 & 0 & 5 & 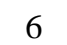 & 3 & 4 & 2 & 3 & 3 & 8 & 3 & \multirow[t]{2}{*}{1.22} & y \\
\hline $\mathbf{W}$ & 0.0 & 0.1 & 0.0 & 0.0 & 0.0 & 0.0 & 0.0 & 0.0 & 0.0 & 0.0 & 0.0 & 0.0 & 0.0 & 0.0 & & 0.0 \\
\hline c & 7 & 1 & 4 & 6 & 5 & 5 & 6 & 7 & 3 & 6 & 5 & 5 & 4 & 7 & \multirow[t]{2}{*}{0.80} & 6 \\
\hline \multirow{2}{*}{$\mathbf{S t}$} & 0.0 & 0.1 & 0.0 & 0.1 & 0.1 & 0.1 & 0.0 & 0.0 & 0.0 & 0.0 & 0.0 & 0.0 & 0.0 & 0.0 & & 0.0 \\
\hline & 7 & 1 & 8 & 1 & 0 & 0 & $\sigma$ & 1 & 7 & 6 & 5 & 5 & 8 & 7 & \multirow[t]{2}{*}{1.07} & 8 \\
\hline \multirow{2}{*}{$\mathbf{E p}$} & 0.0 & 0.1 & 0.0 & 0.0 & 0.0 & 0.0 & 0.1 & 0.0 & 0.0 & 0.0 & 0.0 & 0.1 & 0.0 & 0.0 & & 0.0 \\
\hline & 7 & 1 & 8 & 6 & 5 & 5 & 1 & 7 & 7 & 3 & 5 & 0 & 4 & 7 & 0.95 & 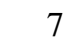 \\
\hline
\end{tabular}




\begin{tabular}{|c|c|c|c|c|c|c|c|c|c|c|c|c|c|c|c|c|}
\hline & 0 & 0.0 & 0.0 & 0.1 & 0.1 & 0.1 & 0.0 & 0.0 & 0.0 & 0.0 & 0.0 & 0.0 & 0.1 & 0.0 & & .0 \\
\hline JK & 7 & 5 & 8 & 1 & 0 & 0 & 6 & 7 & 7 & 6 & 2 & 5 & 6 & 7 & 1.07 & 8 \\
\hline M & 0.0 & 0.0 & 0.0 & 0.1 & 0.1 & 0.1 & 0.0 & 0.0 & 0.0 & 0.3 & 0.0 & 0.0 & 0.0 & 0.0 & & 0.0 \\
\hline $\mathbf{k}$ & 7 & 5 & & & 0 & 0 & & & & & 9 & 5 & 8 & 7 & 1.27 & 9 \\
\hline & 0.1 & 0.0 & 0.0 & 0 & 0.1 & 0. & 0.1 & 0.1 & 0.1 & 0.1 & 0.1 & 0.1 & 0.1 & 0.0 & & 0.1 \\
\hline $1 \mathrm{~J}$ & 1 & 5 & 8 & 6 & 0 & 5 & 1 & 3 & 4 & 2 & 8 & 0 & 6 & 7 & 1.46 & 0 \\
\hline Pl & 0.0 & 0.0 & 0.0 & 0.0 & 0.0 & 0.0 & 0.0 & 0.0 & 0.0 & 0.0 & 0.0 & 0.0 & 0.0 & 0.0 & & 0.0 \\
\hline $1 \mathrm{n}$ & 4 & 5 & 4 & 6 & 5 & 5 & & 3 & 3 & 3 & 5 & 5 & 8 & 1 & 0.68 & 5 \\
\hline & 0.1 & 0.1 & 0.1 & 0.1 & 0.1 & 0.1 & 0.1 & 0.1 & 0.1 & 0.1 & 0.1 & 0.2 & 0.0 & 0.1 & & 0.1 \\
\hline $\mathrm{m}$ & 1 & 1 & 9 & 1 & 0 & 0 & 1 & 3 & 4 & 2 & 8 & 1 & 8 & 3 & 1.83 & \\
\hline & 1 & & & 1 & & 1 & 1 & & 1 & 1 & 1 & 1 & 1 & & 14 & \\
\hline
\end{tabular}

3. Consistency Ratio

Table 3 Consistency Ratio

\begin{tabular}{|c|c|c|c|c|c|c|c|c|c|c|c|c|c|c|c|c|c|}
\hline & & & & & & & & & & & & & & & & & \\
\hline & Le & $\mathrm{Sp}$ & Ns & $\mathrm{Cd}$ & $\mathrm{Cr}$ & Ic & Wc & St & Ep & $\mathrm{Jk}$ & Mk & $\mathrm{Tj}$ & $\mathrm{Pk}$ & $\mathrm{Hh}$ & EP & $\begin{array}{l}\text { Mult } \\
\text { iplic } \\
\text { ation }\end{array}$ & $\begin{array}{l}\text { Divi } \\
\text { sion }\end{array}$ \\
\hline Le & $\begin{array}{c}1.0 \\
0\end{array}$ & $\begin{array}{c}0.5 \\
0\end{array}$ & $\begin{array}{c}1.0 \\
0\end{array}$ & $\begin{array}{c}0.5 \\
0\end{array}$ & $\begin{array}{c}0.5 \\
0\end{array}$ & $\begin{array}{c}1.0 \\
0\end{array}$ & $\begin{array}{c}0.5 \\
0\end{array}$ & $\begin{array}{c}0.5 \\
0\end{array}$ & $\begin{array}{c}0.5 \\
0\end{array}$ & $\begin{array}{c}0.5 \\
0\end{array}$ & $\begin{array}{c}0.5 \\
0\end{array}$ & $\begin{array}{c}0.3 \\
3\end{array}$ & $\begin{array}{c}0.3 \\
3\end{array}$ & $\begin{array}{c}0.3 \\
3\end{array}$ & $\begin{array}{c}0.03 \\
4\end{array}$ & $\begin{array}{c}0.52 \\
7\end{array}$ & $\begin{array}{c}15.3 \\
2\end{array}$ \\
\hline & 2.0 & 1.0 & 1.0 & 0.5 & 1.0 & 1.0 & 0.5 & 0.5 & 1.0 & 0.5 & 1.0 & 1.0 & 0.5 & 0.5 & 0.05 & 0.79 & 14.7 \\
\hline Sp & 0 & 0 & 0 & 0 & 0 & 0 & 0 & 0 & 0 & 0 & 0 & 0 & 0 & 0 & 4 & 2 & 1 \\
\hline Ns & 1.0 & 1.0 & 1.0 & 0.5 & 1.0 & 1.0 & 1.0 & 0.5 & 0.5 & 0.5 & 0.5 & 0.5 & 0.3 & 0.2 & 0.04 & 0.60 & 15.1 \\
\hline Ns & 0 & 0 & 0 & 0 & 0 & 0 & 0 & 0 & 0 & 0 & 0 & 0 & 3 & 0 & 0 & 7 & 6 \\
\hline $\mathrm{C}$ & 2.0 & 2.0 & 2.0 & 1.0 & 1.0 & 1.0 & 1.0 & 0.5 & 1.0 & 0.5 & 0.5 & 1.0 & 0.5 & 0.5 & 0.07 & 0.90 & 12.4 \\
\hline $\mathrm{d}$ & 0 & 0 & 0 & 0 & 0 & 0 & 0 & 0 & 0 & 0 & 0 & 0 & 0 & 0 & 2 & 5 & 8 \\
\hline $\mathrm{Cr}$ & 2.0 & 1.0 & 1.0 & 1.0 & 1.0 & 1.0 & 1.0 & 0.5 & 0.5 & 0.5 & 0.5 & 0.5 & 0.5 & 0.5 & 0.04 & 0.72 & 14.9 \\
\hline $\mathrm{Cr}$ & 0 & 0 & 0 & 0 & 0 & 0 & 0 & 0 & 0 & 0 & 0 & 0 & 0 & 0 & 8 & 5 & 6 \\
\hline & 1.0 & 1.0 & 1.0 & 2.0 & 2.0 & 1.0 & 1.0 & 0.5 & 0.5 & 0.5 & 0.5 & 0.5 & 1.0 & 0.5 & 0.08 & 0.83 & \\
\hline Ic & 0 & 0 & 0 & 0 & 0 & 0 & 0 & 0 & 0 & 0 & 0 & 0 & 0 & 0 & 7 & 6 & 9.60 \\
\hline W & 2.0 & 2.0 & 1.0 & 1.0 & 1.0 & 1.0 & 1.0 & 1.0 & 0.5 & 1.0 & 0.5 & 0.5 & 0.5 & 0.5 & 0.05 & 0.85 & 15.0 \\
\hline $\mathrm{c}$ & 0 & 0 & 0 & 0 & 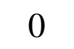 & 0 & 0 & 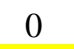 & 0 & 0 & 0 & 0 & 0 & 0 & 7 & 5 & 3 \\
\hline & 2.0 & 2.0 & 2.0 & 2.0 & 2.0 & 2.0 & 1.0 & 1.0 & 1.0 & 1.0 & 0.5 & 0.5 & 1.0 & 0.5 & 0.07 & 1.16 & 15.2 \\
\hline St & 0 & 0 & 0 & 0 & 0 & 0 & 0 & 0 & 0 & 0 & 0 & 0 & 0 & 0 & 6 & 1 & 5 \\
\hline & 2.0 & 1.0 & 2.0 & 1.0 & 2.0 & 2.0 & 2.0 & 1.0 & 1.0 & 1.0 & 1.0 & 0.5 & 0.5 & 0.5 & 0.06 & 1.11 & 16.4 \\
\hline Еp & 0 & 0 & 0 & 0 & 20 & . & 0 & . & 0 & 0 & 0 & 0 & 0 & 0 & 8 & 3 & 7 \\
\hline Th & 2.0 & 1.0 & 2.0 & 2.0 & 2.0 & 2.0 & 1.0 & 1.0 & 1.0 & 1.0 & 0.2 & 0.5 & 1.0 & 0.5 & 0.07 & 1.08 & 14.1 \\
\hline JK & 0 & 0 & 0 & 0 & 0 & 0 & 0 & 0 & 0 & 0 & 0 & 0 & 0 & 0 & 6 & 0 & 7 \\
\hline $\mathrm{M}$ & 2.0 & 1.0 & 2.0 & 2.0 & 2.0 & 2.0 & 2.0 & 2.0 & 1.0 & 5.0 & 1.0 & 0.5 & 2.0 & 0.5 & 0.09 & 1.64 & 18.0 \\
\hline $\mathrm{k}$ & 0 & 0 & 0 & 0 & 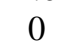 & 0 & . & 0 & 0 & 0 & 0 & 0 & 0 & 0 & 1 & 0 & 9 \\
\hline Ti & 3.0 & 1.0 & 2.0 & 1.0 & 2.0 & 2.0 & 2.0 & 2.0 & 2.0 & 2.0 & 2.0 & 1.0 & 2.0 & 0.5 & 0.10 & 1.58 & 15.1 \\
\hline $1 \mathrm{j}$ & 0 & 0 & 0 & 0 & $\sigma$ & 0 & 0 & 0 & 0 & 0 & 0 & 0 & 0 & 0 & 5 & 3 & 5 \\
\hline & 3.0 & 2.0 & 3.0 & 2.0 & 2.0 & 1.0 & 2.0 & 2.0 & 2.0 & 0.3 & 0.3 & 0.3 & 1.0 & 1.0 & 0.04 & 1.33 & 27.2 \\
\hline $\mathrm{Pk}$ & 0 & 0 & 0 & 0 & 0 & 0 & 0 & 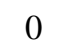 & 0 & 3 & 3 & 3 & 0 & 0 & 9 & 1 & 5 \\
\hline $\mathrm{H}$ & 3.0 & 2.0 & 5.0 & 2.0 & 2.0 & 2.0 & 2.0 & 2.0 & 2.0 & 2.0 & 2.0 & 2.0 & 1.0 & 1.0 & 0.13 & 1.95 & 14.9 \\
\hline $\mathrm{h}$ & 0 & 0 & 0 & 0 & 0 & 0 & 0 & 0 & 0 & 0 & 0 & 0 & 0 & 0 & 1 & 1 & 4 \\
\hline & & & & & & & & & & & & & & & & $\begin{array}{c}15.1 \\
0\end{array}$ & $\begin{array}{c}15.6 \\
1\end{array}$ \\
\hline
\end{tabular}

$$
\begin{aligned}
\mathrm{CI} & =\underline{\lambda \text { mak }-\mathrm{n}} \\
(\mathrm{n}-1) & \\
\mathrm{RI} & =\underline{1,57-(\mathrm{n}-2)} \\
\mathrm{n} & \\
\mathrm{CR} & =\mathrm{CI}
\end{aligned}
$$


RI

Calculation Consistency ratio:

\section{Limitations of research results}

Limitations of the results of this study are the results of research that only applies CV. Indo Global Mandiri in Sidoarjo :

\section{RESULT AND DISCUSION}

Table 4 Final Results Weighting Criteria Weight Ranking

\begin{tabular}{|l|l|l|}
\hline Criteria & Value & Rank \\
\hline $\begin{array}{l}\text { harmonious relations among } \\
\text { fellow employees } \\
\text { both responsibilities with } \\
\text { weights } \\
\text { the three control mechanisms } \\
\text { by direct supervisors } \\
\text { implicit control mechanism }\end{array}$ & 0,131 & I \\
\hline
\end{tabular}

From The table above shows that designing an Organizational Culture that can be applied in a company is harmonious relations among fellow employees with a weight of 0.131 , both responsibilities with weights 0.105 , and the three control mechanisms by direct supervisors weighing 0.091 and the last implicit control mechanism with a weight of 0.087 .

\section{CONCLUSION}

1. The criteria that most play a role in designing organizational culture is the criteria for harmonizing relationships 0.131 . The second priority is the criteria of responsibility with a weight of 0105 . The third priority is the criterion of the control mechanism weighing 0.091 and for the latter the role is the criterion of the control mechanism with a weight of 0.087

2. From the weighting results above the design of organizational culture within the CV. Indobenua Global Mandiri Sidoarjo was formed through a modification of the value system derived from the $\mathrm{Z}$ Theory such as: implicit control mechanism and with the prevailing culture in the environment of CV. Global Global Mandiri such as: harmonizing relationships between employees, and, responsibilities according to job des control mechanism by direct supervisor. Overall the organizational culture that is formed is to build harmonious relationships between employees and superiors, then responsibility according to job des, and control of the work carried out by each individual employee but also control (supervision) by direct supervisor.

\section{SUGGESTION}


Based on the results of the analysis and the conclusions above, the authors propose the following suggestions:

1. With the formation of organizational culture through value management: harmonizing relationships among employees, responsibilities according to job des, implicit control mechanism and concentual decision making (decisions according to consensus). Four values are expected to be able to formulate indicators of each value system, so that it can be used as a guideline for every employee in the company environment.

2. For further research the results of this study can be used as a reference in designing organizational culture by elaborating Z Theory with other organizational cultural theories.

\section{REFERENCES}

Mangkunegara,Prabu A.A.Anwar (2005) ORGANIZATIONAL BEHAVIOR AND CULTURE. Edited by R. Herlina.

Yusuf,H.Burhanuddin (2015) Human resource management in Islamic Financial Institutions. Edited by MNR Al Arif. PT RajaGrafindo Persada, Jakarta.

Ali Muhammad (2012) Secondary Education Policy in Indonesia's Governance Perspective.

S.Hermawan (2009) 'Culture and Modification of Z Theory in Indonesia Sigit Hermawan', 7 (2), pp. $1-16$.

Scientific, P. et al. (2016) 'MODA SELECTION MODEL WITH AHP (ANALYTICAL

HIERARCHY PROCESS) METHOD (Case Study: Palur Housing, Ngringo Village, Jaten

District, Karanganyar Regency)'. Available at: eprints.ums.ac.id.

Sources of Organizational Culture (2001). Available at: https: // kulpulanmateri.blogspot.com/2012/05/sumber-sumber-budaya-organsasi.html.

Saragih Hartati Sylvia (2013) APPLICATION OF ANALITYCAL HIERARCHY PROCESS (AHP) METHOD IN LAPTOP SELECTION DECISION SUPPORT SYSTEM. 